\title{
Tracking the Release of Soil Nitrate and Labile C in A Legume-Maize Rotation in Zimbabwe
}

\author{
Obert Jiri $^{1,2}$ \& Paramu L Mafongoya ${ }^{1}$ \\ ${ }^{1}$ School of Agricultural, Earth and Environmental Sciences, University of KwaZulu-Natal, Private Bag X01, \\ Scottsville, Pietermaritzburg, 3209, South Africa \\ ${ }^{2}$ Agricultural Practice, Faculty of Agriculture, University of Zimbabwe, P. O. Box MP167 Mt Pleasant, Harare, \\ Zimbabwe \\ Correspondence: Obert Jiri, School of Agricultural, Earth and Environmental Sciences, University of \\ KwaZulu-Natal, Private Bag X01, Scottsville, Pietermaritzburg, 3209, South Africa. E-mail: \\ obertjiri@yahoo.co.uk
}

Received: February 3, 2017 Accepted: February 17, 2017 Online Published: November 28, 2017

doi:10.5539/sar.v7n1p92 URL: https://doi.org/10.5539/sar.v7n1p92

\begin{abstract}
This study compared the effect of a weedy fallow (5.2 t/ha biomass), a velvet bean (Mucuna pruriens) cut for hay (7.2 t/ha biomass) and a green-manured M. pruriens (6.49 t/ha biomass) on the dynamics of soil $\mathrm{N}$ and $\mathrm{C}$ in a maize crop. An on-farm, farmer participatory experiment was established on a farmer's field in Wedza District, Zimbabwe. Soil mineral $\mathrm{N}$ and labile carbon were determined at intervals upto $120 \mathrm{~cm}$ depth, at maize planting and at 1 and 2 weeks after planting. Before planting, the soil mineral $\mathrm{N}$ content ranged from $28 \mathrm{~kg} \mathrm{~N} / \mathrm{ha}$ after weed fallow to $107 \mathrm{kgN} / \mathrm{ha}$ following M. pruriens. Total nitrate concentration was highest in the $0-15 \mathrm{~cm}$ depth of the M. pruriens treatments in the pre-planting sampling, but following rainfall and maize planting, nitrate concentration declined rapidly. By 2 weeks after planting, 7.5 and $13.5 \mathrm{~kg} \mathrm{~N} / \mathrm{ha}$ remained in the $0-120 \mathrm{~cm}$ soil depth of the weedy fallow and green-manured $M$. pruriens, respectively. Improving synchrony of nutrient release and uptake is critical when applying high quality residues which breakdown relatively slowly. This could result in significant inputs of $\mathrm{C}$, release nutrients more slowly and reduce soil nutrient losses.
\end{abstract}

Keywords: forage legumes, green manures, leaching, nitrogen, carbon

\section{Introduction}

Soil organic matter (SOM) is considered to be a key factor in maintaining soil quality and is therefore crucial in determining long-term soil fertility (Bationo, 2007). Much evidence indicates that the decline in crop yield with continued production in many temperate and tropical areas is correlated with declines in organic matter levels (Sanchez \& Leakey, 2004). Therefore maintaining soil organic matter must be considered as one of the goals of sustainable land management systems.

In many cropping systems, soil management to increase SOM and supply nitrogen for crop production has generally been approached via the use of green manuring and crop residue retention. The application of green manures often results in increases in crop yield. However, there is no evidence of long-term improvement of SOM and soil fertility (Rurinda et al., 2014). Green manuring produces short-term pulses of nutrients into the soil, resulting from extremely rapid oxidation of $\mathrm{C}$ and nutrients due to the rapid decomposition of the added material (Waddington, 2003). Conversely, lower quality crop residue (e.g. cereal straw) releases nutrients too slowly, and in insufficient quantities to meet microbial and crop requirements. As an alternative, the application of high quality residues, which breakdown relatively rapidly due to their chemical and/or physical attributes and improved mineralisation of nutrients, could result in significant increases in soil C, provide plant nutrients for longer periods and reduce soil nutrient losses.

This experiment was established to compare the effect of a weedy fallow, a grazed $M$. pruriens pasture and a ploughed in/green manured M. pruriens system on the dynamics of soil $\mathrm{N}$ and $\mathrm{C}$ prior to planting and up to 2 weeks after planting of a maize crop in the season following the weedy fallow/ M. pruriens treatments. 


\section{Method}

\subsection{Site Description}

The experiment was carried out in Hwedza District, Zimbabwe, in Zana resettlement area. The resettled farming community of Zana (longitude of $18^{\circ} 54^{\prime} \mathrm{S}$, latitude of $31^{\circ} 59^{\prime} \mathrm{E}$ ) lies in Natural Region IIb (Surveyor-General, 1984), $80 \mathrm{~km}$ south of Marondera and $150 \mathrm{~km}$ south east of Harare in Zimbabwe. Farming in these areas is based on infertile deep brown sands to sandy loam soils that are derived predominantly from granite and supporting a range of farming and livestock systems. Mean annual rainfall ranges from 600-900 mm per annum with most of it falling between November and March. Major limitations to maize production are soil nitrogen and phosphorus deficiencies. The limited cash reserves of the predominantly subsistence farmers result in the application of very little, or no, inorganic fertilizers to their crops. Farming systems that can supply nitrogen through biological N fixation are being investigated. An on-farm, farmer participatory experiment was established on a sandy soil site at Zana communal area. The aim of the main experiment was to determine the residual effects of forage legumes Vigna unguiculata, (cowpea), M. pruriens (velvet bean), Macrotyloma axillare/Chloris gayana cv. Katambora, weed fallows or sole maize grown in the 1999/2000 wet season on a subsequent maize crop grown in 2000/2001 season.

\subsection{Treatment Details and Soil Sampling}

Three treatments (established on $8 \times 9 \mathrm{~m}$ plots), namely weed fallow, M. pruriens that was removed for hay, and M. pruriens that was ploughed into the soil, were soil sampled at the start of the wet season in 2000/2001 to investigate the dynamics of $\mathrm{C}$ and $\mathrm{N}$ in these systems. Soil characteristics of the site are shown in Table 1.

Weeds were not controlled on the weed fallow, and legume grain was harvested from the $M$. pruriens plots. Plant dry matter biomass was determined on all three treatments. Total above ground biomass was measured at fallow clearing by separating the biomass components into foliage (leaves and twigs), branches and stems. These components were then weighed as fresh biomass after which samples of each component were collected on plot basis and oven dried at $70^{\circ} \mathrm{C}$ to equilibrium moisture content. This data was used to estimate dry weight on plot basis and extrapolated to a hectare basis. The plant material from the hay M. pruriens treatments was removed at maturity to simulate a hay system while the M. pruriens biomass was ploughed-in in May 2000 for the green manure treatments. Grazing livestock were allowed access to these areas during the dry season as it is situated in the community cropping areas. Maize stover, as is usual practice in communal areas, would have been removed from the fields at harvesting.

Soil samples (taken at 0-15, 15-30, 30-60, 60-90 and 90-120 cm depths) were collected following the opening wet season rains (24/25 October 2000), at maize planting (28/29 November 2000), 1 week after planting (WAP) (6 December 2000) and 2 WAP (13/14 December 2000). Soil nitrate-N, total $N\left(N_{T}\right)$, total and labile carbon $\left(C_{L}\right.$ $333 \mathrm{mM} \mathrm{KMnO}_{4}$ oxidisable $\mathrm{C}$ ) were determined on these samples.

The soils were analysed for total organic carbon $\left(\mathrm{C}_{\mathrm{T}}\right)$ by combustion (Leco), and labile organic carbon $\left(\mathrm{C}_{\mathrm{L}}\right)$ (UNE method, Blair et al. 1995). Non labile carbon $\left(C_{N L}\right)$ is calculated as the difference between the $C_{T}$ and $\mathrm{C}_{\mathrm{L}}(333 \mathrm{mM})$ pools. Lability $(\mathrm{L})$, an index of the 'quality' of $\mathrm{C}_{\mathrm{T}}$, is calculated by dividing $\mathrm{C}_{\mathrm{L}}$ by $\mathrm{C}_{\mathrm{NL}}$. $\mathrm{C}_{\mathrm{L}}$ fractions oxidized by 33 and $333 \mathrm{mM} \mathrm{KmnO}{ }_{4}$ will reflect 2 pools of carbon compounds based on their lability (Loginow, et al. 1987). The weakest concentration, $\left(33 \mathrm{mM} \mathrm{KMnO}_{4}\right)$ will oxidize the most labile compounds, while the stronger concentration $\left(333 \mathrm{mM} \mathrm{KMnO}_{4}\right.$ ) will oxidize more carbon compounds.

\subsection{Statistical Analysis}

Genstat version 14.0 statistical package was used for data analysis. Treatment differences were tested in an Analysis of Variance and least significant difference was used to calculate mean separation. Statistical significance was declared at $\mathrm{P} \leq 0.05$.

\section{Results}

\subsection{Plant Biomass Yield}

Total biomass measured at the end of the 1999/2000 wet season (reported in detail in the thesis of Jiri (2003)) was $5.22 \mathrm{t} / \mathrm{ha}$ on the weed fallow, $7.15 \mathrm{t} / \mathrm{ha}$ on the $M$. pruriens treatment cut for hay and $6.49 \mathrm{t} / \mathrm{ha}$ on the green manured $M$. pruriens treatment. The Mucuna treatemnts produced significantly higher amounts of biomass compared to the weedy fallow $(\mathrm{P} \leq 0.05)$.

\subsection{Soil Properties}

The sandy soil was highly acidic, with the $\mathrm{pH}\left(\mathrm{CaCl}_{2}\right)$ below 4.5 and very low in the cations $\mathrm{K}^{+}, \mathrm{Ca}^{++}$and $\mathrm{Mg}^{++}$ (Table 1) reflecting very low soil organic matter $\left(\mathrm{C}_{\mathrm{T}}<0.9 \%\right.$ Table 2$)$ and associated low cation exchange capacity. 
Available $\mathrm{P}$ was marginal in the $0-15 \mathrm{~cm}$ depth and low in the $15-30 \mathrm{~cm}$ depth $(\mathrm{P} \leq 0.05)$.

Table 1. Soil characteristics at the experimental site

\begin{tabular}{|c|c|c|c|c|c|c|c|}
\hline & Texture & Depth & $\mathrm{pH}$ & $\mathrm{K}$ & $\mathrm{Mg}$ & $\mathrm{Ca}$ & $\mathrm{P}($ Bicarb $)$ \\
\hline \multirow{3}{*}{ Mbavha } & \multirow{3}{*}{ Sandy soil ( $65 \%$ sand) } & $(\mathrm{cm})$ & $\left(\mathrm{CaCl}_{2}\right)$ & & $-\mathrm{cm}$ & $-/ \mathrm{kg}$ & $-(\mathrm{mg} / \mathrm{kg})$ \\
\hline & & $0-15$ & 4.28 & 0.12 & 0.12 & 0.64 & 17 \\
\hline & & $15-30$ & 4.02 & 0.06 & 0.07 & 0.25 & 6 \\
\hline
\end{tabular}

\subsection{Organic Carbon}

Soil organic carbon was determined on samples collected from the weed fallow and M. pruriens cut for hay treatments (so as to manage cost of analysis) at pre-planting (Table 2) and at 2 WAP (data not shown). Total C, $\mathrm{C}_{\mathrm{L}}$ and Lability declined down the profile. There were generally minor differences between the treatments in $\mathrm{C}_{\mathrm{L}}$, Lability and $\mathrm{N}_{\mathrm{T}}$ between the treatments and the two sampling times.

Table 2. Total, non-labile and labile $\mathrm{C}$ pools and total $\mathrm{N}$ of the weed fallow and M. pruriens cut for hay treatments at pre-planting.

\begin{tabular}{|c|c|c|c|c|c|c|c|}
\hline Depth $(\mathrm{cm})$ & $\mathrm{C}_{\mathrm{T}}$ & $\mathrm{C}_{\mathrm{NL}}{ }^{\mathrm{A}}$ & $\begin{array}{l}\mathrm{C}_{\mathrm{L}}\left(33 \mathrm{mM} \mathrm{KmNO}{ }_{4}\right) \\
\mathrm{gg} / \mathrm{g}\end{array}$ & $\mathrm{C}_{\mathrm{L}}\left(333 \mathrm{mM} \mathrm{KmNO} \mathrm{Km}_{4}\right)$ & Lability $^{\mathrm{B}}$ & $\begin{array}{l}\mathrm{N}_{\mathrm{T}} \\
\mathrm{mg} / \mathrm{g}\end{array}$ & $\mathrm{C}: \mathrm{N}$ \\
\hline \multicolumn{8}{|l|}{ Weed Fallow } \\
\hline$(0-15)$ & 5.13 & 4.22 & 0.45 & 0.91 & 0.22 & 0.41 & 12.51 \\
\hline$(15-30)$ & 3.11 & 2.76 & 0.20 & 0.35 & 0.13 & 0.26 & 11.96 \\
\hline$(30-60)$ & 4.72 & 3.97 & 0.39 & 0.75 & 0.19 & 0.48 & 9.83 \\
\hline$(60-90)$ & 1.85 & 1.72 & 0.08 & 0.13 & 0.08 & 0.22 & 8.41 \\
\hline$(90-120)$ & 1.54 & 1.50 & 0.06 & 0.04 & 0.03 & 0.29 & 5.31 \\
\hline \multicolumn{8}{|c|}{ M. pruriens (Hay) } \\
\hline$(0-15)$ & 4.28 & 3.67 & 0.30 & 0.61 & 0.17 & 0.46 & 9.30 \\
\hline$(15-30)$ & 4.66 & 4.26 & 0.30 & 0.40 & 0.09 & 0.39 & 11.95 \\
\hline$(30-60)$ & 2.89 & 2.63 & 0.20 & 0.26 & 0.10 & 0.3 & 9.63 \\
\hline$(60-90)$ & 2.65 & 2.40 & 0.10 & 0.25 & 0.10 & 0.18 & 14.72 \\
\hline$(90-120)$ & 4.10 & 3.87 & 0.20 & 0.23 & 0.06 & 0.38 & 10.79 \\
\hline \multicolumn{4}{|c|}{ SED(Standard Error of the Difference) (depth) } & 0.09 & & & \\
\hline \multicolumn{4}{|c|}{ LSD (Least Significant Difference)(depth) } & 0.03 & & & \\
\hline \multicolumn{4}{|c|}{ P (Probability) (depth) } & 0.001 & & & \\
\hline
\end{tabular}

$$
{ }^{\mathrm{A}} \mathrm{C}_{\mathrm{NL}}=\mathrm{C}_{\mathrm{T}}-\mathrm{C}_{\mathrm{L}}(333 \mathrm{mM}){ }^{\mathrm{B}} \mathrm{L}=\frac{\mathrm{C}_{\mathrm{L}(333 \mathrm{~mm})}}{\mathrm{C}_{\mathrm{NL}}}
$$

\subsection{Nitrate}

The concentrations of nitrate at the site throughout the soil profile across the 4 sampling times are presented in a time series format in Figure 1a, b, c and d. The highest concentrations of nitrate were found at the pre-planting sampling in the 0-15 layers of all three treatments. Nitrate concentration was highest following the M. pruriens cut for hay and the green manured treatments, 21 and $30 \mathrm{mg} / \mathrm{kg}$ respectively, compared with only $7 \mathrm{mg} / \mathrm{kg}$ in the weedy treatment $(\mathrm{P} \leq 0.05)$. Total nitrate content of the profiles, calculated from the nitrate concentration and bulk density to $120 \mathrm{~cm}$ (Figure 2), were highest at the pre-planting sampling and showed that the M. pruriens cut for hay treatment contained $107 \mathrm{~kg} \mathrm{~N} / \mathrm{ha}$ compared to 68 and $28 \mathrm{~kg} \mathrm{~N} / \mathrm{ha}$ on the green manure and weedy fallow treatments, respectively.

By planting and after $32 \mathrm{~mm}$ of rain, nitrate in the $0-15 \mathrm{~cm}$ layer of the $M$. pruriens cut for hay treatment remained stable. However, the green manure M. pruriens treatment had declined by almost two thirds to 11 $\mathrm{mg} / \mathrm{kg}$ with a corresponding increase in the $15-30 \mathrm{~cm}$ layer. The total nitrate content declined between these two samplings (Figure 2).

The samplings at 1WAP (rainfall total $78 \mathrm{~mm}$ ) and 2 WAP (rainfall total $111 \mathrm{~mm}$ ) indicated very little nitrate in the $0-15 \mathrm{~cm}$ depth $(2 \mathrm{mg} / \mathrm{kg})$ in all the treatments. A bulge of nitrate at the $15-30 \mathrm{~cm}$ depth of both M. pruriens treatments can be seen in Figure 1c and may indicate leaching of $\mathrm{N}$ from the surface layers that were initially higher in nitrate.

By 2 WAP the 3 treatments contained less than $4 \mathrm{mg} / \mathrm{kg}$ at all sampling depths. Total $\mathrm{N}$ content was still highest 
in the $M$. pruriens cut for hay treatment $(26 \mathrm{~kg} \mathrm{~N} / \mathrm{ha})$ but the green manure $M$. pruriens and weedy treatments contained only 7.5 and $13.5 \mathrm{~kg} \mathrm{~N} / \mathrm{ha}$, respectively (Figure 2$)(\mathrm{P} \leq 0.05)$.

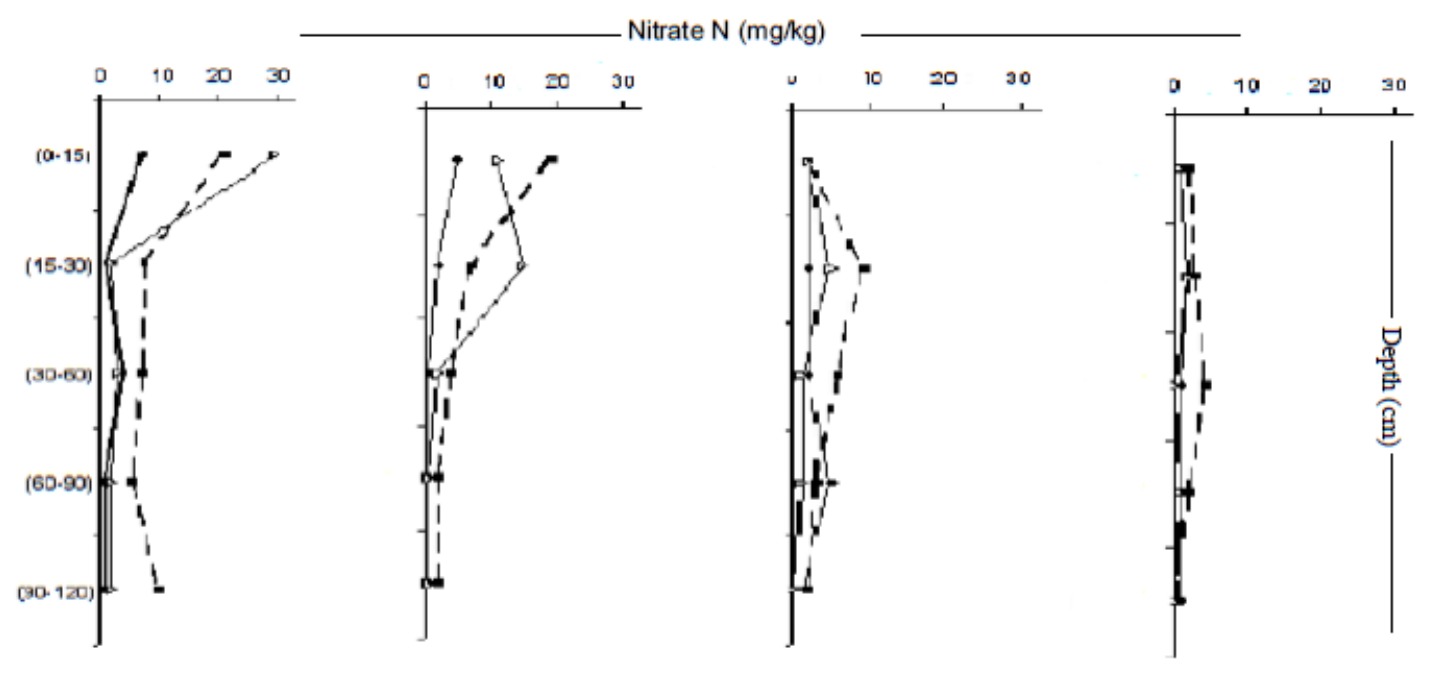

1a. Pre-planting

1b. Planting

1c. 1WAP

1d. 2WAP

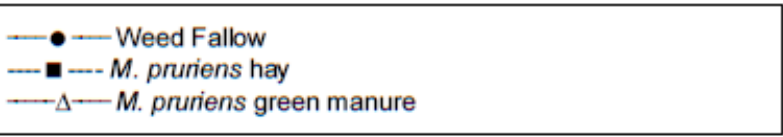

Figure 1. Nitrate $\mathrm{N}$ concentration of the Mbavha sandy soil site

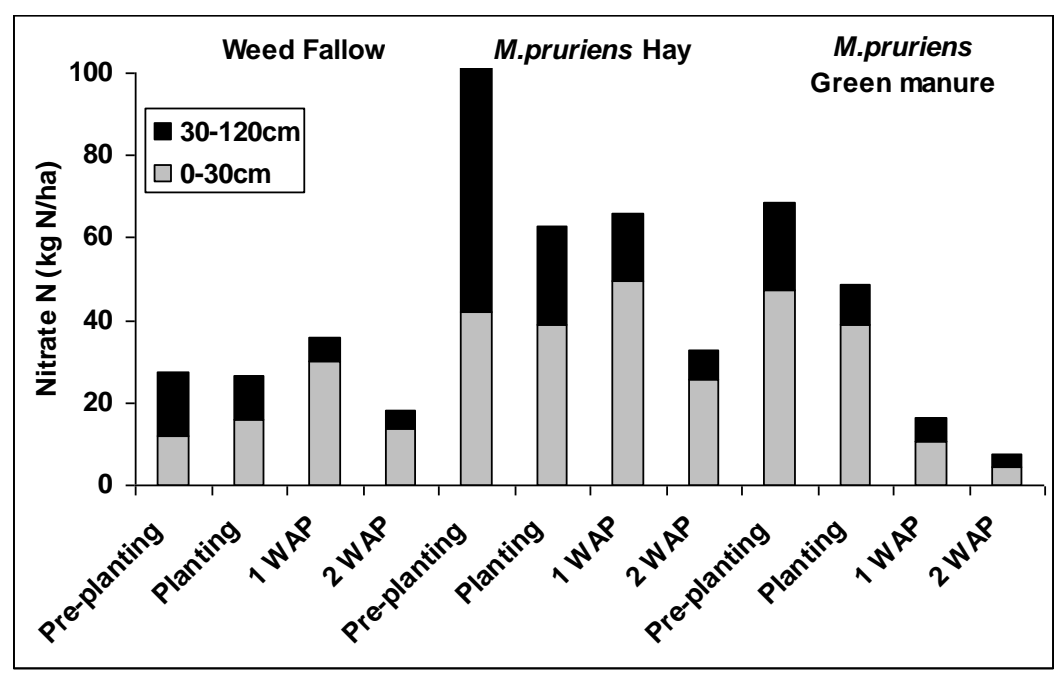

$$
\mathrm{SED}=4.15 \mathrm{kgNha}^{-1}, \mathrm{P} \leq 0.05 .
$$

Figure 2. Total soil nitrate in the $0-30$ and $30-120 \mathrm{~cm}$ soil depth at the four sampling times

\section{Discussion}

The initially high nitrate concentrations at the pre-planting sampling were confined to the $0-15 \mathrm{~cm}$ layer of the $M$. pruriens treatments. These higher concentrations reflect the addition of $\mathrm{N}$ in the legume residues grown during the previous season. The production of 7.15 and $6.49 \mathrm{t} / \mathrm{ha}$ of $M$. pruriens biomass in the cut for hay and green manured plots during the 1999/2000 wet season results in approximately 178 and $162 \mathrm{~kg} \mathrm{~N} / \mathrm{ha}$, respectively, contained in the plant material (a large proportion of this would be from biological $\mathrm{N}$ fixation). Ploughing in the M. pruriens prior to the dry season ensured that plant residues were unavailable to the animals. This is reflected 
in the highest pre-planting nitrate concentration of this treatment (Figure 1 a). According to the local farmers, and Mr Mbavha who owned the land on which these experiments were conducted, it is unlikely that they would plough in high quality plant materials given the shortage of feed during the dry season. Harvesting, storing and feeding the plant material to penned animals is a much more likely scenario. Unfortunately much of the manure ends up staying in the kraals (penned areas) or spread around the homestead fields, with the large associated $\mathrm{N}$ losses (Zingore, 2006). Chikowo et al. (2004) also measured a rapid decline in mineral nitrogen between 1 and 3 WAP of a maize crop following M. pruriens, cattle manure, soyabean and fertiliser additions. They showed there were very few maize crop roots below $20 \mathrm{~cm}$ before $4 \mathrm{WAP}$, leaving nitrate susceptible to leaching. No increases in labile $\mathrm{C}$ at depth $\left(33 \mathrm{mM}\right.$ or $333 \mathrm{mM} \mathrm{KMnO}_{4}$ labile $\mathrm{C}$ ) were detected as evidence of soluble $\mathrm{C}$ compounds leaching.

The higher nitrate content of the treatments cut for hay at all sampling times (Figure 2) throughout the trial may reflect a combination of the slightly higher $M$. pruriens biomass achieved in the previous season, and inputs of manure while the animals were grazing the residues. Even though the residues were removed from this simulated grazing treatment prior to the dry season, $\mathrm{N}$ inputs from the roots and leaf-fall throughout the growth of crop have become significant. This is supported by results obtained by Mafongoya and Jiri (2016) working on similar soils in central Zambia.

It is likely that more intensive sampling at the start of the rain season and throughout the growth of a maize crop would help explain disappearance of soil mineral $\mathrm{N}$ in the soil profile and the generally low recoveries on legume N (Ambrosano et al. 2013). While no labile $\mathrm{C}$ was measured at depth in this study, it is likely that the labile $\mathrm{C}$ and $\mathrm{N}$ compounds were leached with the rainfall events between the sampling times. This is supported by findings by Bationo et al (2007) in work carried out in West Africa on sandy soils.

The distinct dry season in the experimental area means there is little or no rainfall between harvest of the $M$. pruriens and land preparation for a maize crop for the subsequent season. This dry season stops most mineralisation of the plant litter and the potential for leaching of the nitrate $\mathrm{N}$. The opening wet season rains are at a time of warm soil temperatures and the conditions for rapid mineralisation of leguminous material are optimum. It is under these conditions that synchronising nutrient release from high quality leguminous residues with nutrient uptake of a cereal crop is impossible. Mineralisation and leaching of $\mathrm{N}$ and $\mathrm{C}$ from high quality leguminous residues occur rapidly and changes can be measured days after the wetting event (Nguyen et al. 2014).

The nitrogen benefit to maize in rotation with legumes is mostly derived from nitrogen left in crop residue. These results show that, although $\mathrm{N}$ supply processes are important, they seldom provide abundance of $\mathrm{N}$ for long enough to sustain production on the same land (Khosla et al., 2002). Decomposition of high quality materials, such as legume residues, release mineral N. During decomposition there is a partitioning of $\mathrm{N}$ first between mineral $\mathrm{N}$ and microbial $\mathrm{N}$, then with turnover of microbial $\mathrm{N}$, into mineral $\mathrm{N}$, humic $\mathrm{N}$ and microbial $\mathrm{N}$ (CGIAR, 2012). The availability of the $\mathrm{N}$ accumulated in soil organic matter to subsequent crops following the various legume-based treatments is a critical issue.

\section{Conclusions and Recommendations}

This dataset raises the difficulty of synchronizing nutrient release from leguminous plants with the demand of a growing crop such as maize. It is clear that although significant amounts of nitrate can be supplied by legumes, much of the becomes available early in the wet season and can move below $30 \mathrm{~cm}$ prior to crop roots growing to this depth. Since nitrogen demands of most crops are maximised during floral initiation and flowering, the use of $\mathrm{N}$ from the M. pruriens may be inefficient. Significant gains in the efficiency of $\mathrm{N}$ recovery can be made when plant material of slower decomposition rates is added to highly decomposable green manure materials. Wijnhoud et al (2003) found that adding rice straw to the green manure Aeschynomene afraspera, which is used as a green manure crop for flooded paddy rice, increased the $\mathrm{N}$ recovery efficiency in a subsequent rice crop from 29 to $50 \%$. If smallholder farmers intend to use $M$. pruriens on maize as an $\mathrm{N}$ source, removing and storing the green manure plant residues during the wet season and adding them to the germinating maize mixed with maize stover or other low quality organic residues is likely to improve $\mathrm{N}$ recovery and increase soil organic matter contents over the longer term. This is, however, a highly labour intensive job.

\section{References}

Ambrosano, E. J., Cantarella, H., Bovi Ambrosano, G. M., Ferreira Dias, F. L., Rossi, F., Ocheuze Trivelin, P. C., \& Muraoka, T. (2013). The role of green manure nitrogen use by corn and sugarcane crops in Brazil. Agricultural Sciences, 04(12), 89-108. https://doi.org/10.4236/as.2013.412A008 
Bationo, A. (2007). Advances in Integrated Soil Fertility Management in sub-Saharan Africa: Challenges and Opportunities: Challenges and Opportunities. Springer Science \& Business Media. https://doi.org/10.1007/978-1-4020-5760-1

Bationo, A., Kihara, J., Vanlauwe, B., Waswa, B., \& Kimetu, J. (2007). Soil organic carbon dynamics, functions and management in West African agro-ecosystems. Agricultural Systems, 94(1), 13-25.

https://doi.org/10.1016/j.agsy.2005.08.011

CGIAR. (2012). Leveraging legumes to combat poverty, hunger, malnutrition and environmental degradation. Retrieved December 20, 2015, from http://www.icrisat.org/crp/CRP3.5_Grain_Legumes_15Aug12.pdf

Chikowo, R., Mapfumo, P., Nyamugafata, P., \& Giller, K. E. (2004). Mineral N dynamics, leaching and nitrous oxide losses under maize following two-year improved fallows on a sandy loam soil in Zimbabwe. Plant and Soil, 259(1-2), 315-330. https://doi.org/10.1023/B:PLSO.0000020977.28048.fd

Jiri, O. (2003). Mineral nutrition and integration of forage legumes into smallholder farming systems, with emphasis on velvet bean [ Mucuna pruriens ( L ) DC. University of Zimbabwe, MPhil Thesis, (December).

Khosla, R., Fleming, K., Delgado, J. a, Shaver, T. M., \& Westfall, D. G. (2002). Use of site-specific management zones to improve nitrogen management for precision agriculture. Journal of Soil and Water Conservation, 57(6), 513-518. Retrieved from http://www.jswconline.org/content/57/6/513.abstract

Nguyen, D. H., Biala, J., Grace, P. R., Scheer, C., \& Rowlings, D. W. (2014). Greenhouse gas emissions from sub-tropical agricultural soils after addition of organic by-products. SpringerPlus, 3(1), 491. https://doi.org/10.1186/2193-1801-3-491

Paramu L Mafongoya; Obert Jiri. (2016). Nutrient Availability Following Planted Tree Fallows and Benefits to Subsequent Maize Crops. International Journal of Agriculture Innovations and Research, 4(5), 818-823. Retrieved from http://www.ijair.org/index.php/issues

Rurinda, J., Mapfumo, P., Van Wijk, M. T., Mtambanengwe, F., Rufino, M. C., Chikowo, R., \& Giller, K. E. (2014). Sources of vulnerability to a variable and changing climate among smallholder households in Zimbabwe: A participatory analysis. Climate Risk Management, 3, 65-78. https://doi.org/10.1016/j.crm.2014.05.004

Sanchez, P. A., Buresh, R. J., \& Leakey, R. R. B. (2004). Trees, soils, and food security. Philosophical Considerations of the Royal B: Biological Sciences, 352(1356).

Surveyor General. (1984). Zimbabwe. Natural Regions and Farming Areas. Government of Zimbabwe. Harare, Zimbabwe.

Waddington, S. R. (2003). Grain Legumes and Green Manures for Soil Fertility in Southern Africa: Taking Stock of Progress. Proceedings of a Conference Held 8-11 October 2002 at the Leopard Rock Hotel, Vumba, Zimbabwe. Soil Fert. Net and CIMMYT-Zimbabwe, Harare, Zimbabwe. Retrieved from https://books.google.com/books?id=x0bNhhtdUicC\&pgis=1

Wijnhoud, J. D., Konboon, Y., \& Lefroy, R. D. B. (2003). Nutrient budgets: Sustainability assessment of rainfed lowland rice-based systems in northeast Thailand. Agriculture, Ecosystems and Environment, 100(2-3), 119-127. https://doi.org/10.1016/S0167-8809(03)00180-4

Zingore, S. (2006). Exploring diversity within smallholder farming systems in Zimbabwe. Nutrient use efficiencies and resource management strategies for crop production. PhD Thesis. Wageningen University. The Netherlands.

\section{Copyrights}

Copyright for this article is retained by the author(s), with first publication rights granted to the journal.

This is an open-access article distributed under the terms and conditions of the Creative Commons Attribution license (http://creativecommons.org/licenses/by/3.0/). 